\title{
REGIONAL ECONOMIC INTEGRATION, MOBILITY OF PRODUCTION FACTORS AND THE ROLE OF CENTRAL BANK
}

\author{
Haris Munandar, Ferry Kurniawan, Oki Hermansyah ${ }^{1}$
}

\begin{abstract}
Abstraks i
Penelitian ini menunjukkan bahwa dalam perekonomian yang terintegrasi penuh yang memungkinkan pergerakan input dan output secara bebas, maka proporsi output dalam perekonomian akan sama dengan proporsi input produktif (yakni physical dan human capital). Ini kami sebut sebagai hubungan proporsional (equal-share relationship).

Hubungan ini juga berlaku ketika terdapat perbedaan teknologi atau perbedaan biaya pergerakan input lintas sektor dengan syarat input dan output ini diukur dengan benar dalam merefleksikan perbedaan biaya tersebut. Dalam suatu perekonomian yang terintegrasi, hubungan proporsional ini membatasi distribusi input dan output. Selain itu, hubungan proporsional ini sekaligus memberikan batasan pengambilan kebijakan yang dapat mempengaruhi perkembangan setiap sektor dalam perekonomian yang terintegrasi penuh. Disini investasi memainkan peranan kunci dalam menentukan distribusi produksi.

Dengan aplikasi teknik analisis panel pada data negara ASEAN, penelitian ini menelusuri dampak kebijakan moneter terhadap investasi. Hasil penelitian menunjukkan: (i) bank sentral melalui kebijakan moneternya memberikan pengaruh yang signifikan terhadap kinerja investasi, (ii) inflasi yang rendah dan stabilitas perekonomian secara signifikan meningkatkan investasi. Menyongsong terbentuknya ASEAN Economic Community, temuan ini menegaaskan peran penting bank sentral dalam meningkatkan investasi.
\end{abstract}

JEL Classification: E13, F15, F21, F22, O57

Keywords: distribusi produksi, pertumbuhan, mobilitas input, kebijakan moneter, integrasi, ASEAN.

1 Haris Munandar is an Economist while Ferry Kurniawan and Oki Hermansyah are Junior Economists at the Modeling and Outlook Unit of Bureau of Economic Research, Directorate of Economic Research and Monetary Policy, Bank Indonesia, Jl. M.H. Thamrin No. 2, Jakarta 10350, Indonesia; email: hmunandar@bi.go.id (corresponding author). The views expressed in this paper are those of the authors and do not necessarily represent those of Bank Indonesia or Bank Indonesia policy. We thank Made Sukada, Wijoyo Santoso, Endy Dwi Tjahjono and conference participants at the Asia Pacific Trade Seminars (APTS) in Sidney, 14-15 July 2008, for providing us comments and encouraging us to do this work. 


\section{INTRODUCTION}

At the January 2007 ASEAN Summit in Cebu, Philippines, ASEAN leaders agreed to bring forward to 2015 an ambitious initiative to integrate their economies and establish an ASEAN Economic Community (AEC). The community was previously planned to be instituted by 2020 as per earlier ASEAN leaders' decision at the 2003 ASEAN Summit in Bali. The main motivation in the beginning was the need for a significantly higher level of regional economic integration if the ASEAN economies were to compete in a world in which the weight of China and India would continue to rise. The AEC is now aspired to be a single market and production base, a highly competitive economic region, a region of equitable economic development and a region that is fully integrated into the global economy. To achieve such objectives an AEC blueprint was launched at a more recent ASEAN Summit in Singapore in November 2007. This blueprint is intended to be the roadmap required to implement the AEC by 2015. The manuscript contains action plans, targets and timelines for the implementation of the various economic initiatives to advance the AEC.

Developing an ASEAN single market and production base necessitates achieving free flow of goods, services, investment, capital and skilled labor. To this end, 12 priority sectors have been selected as the catalyst and these sectors will pursue a fast track integration path. ${ }^{1}$ In this context, the ASEAN Free Trade Area (AFTA) has been one of the most important building blocks of the AEC as it has facilitated the agenda towards free movement of goods in the region. AFTA was formed in January 1992 at the ASEAN Summit meeting in Singapore. By now, tariff rates reduction to 0 to 5 percent under AFTA have been adopted by most member countries with full implementation by all members from 2010. Brunei, Indonesia, Malaysia, Philippines, Singapore and Thailand (referred to as the ASEAN-6) agreed to complete the comprehensive tariff reduction program in 2008 which was moved forward to 2002. Cambodia, Laos, Myanmar and Viet Nam (CLMV countries) were given longer time frames to complete the program: Viet Nam in 2006, Laos and Myanmar in 2008 and Cambodia in 2010.

Conceptually, the AEC is intended to mimic a European Union (EU)-style single market. Within the ASEAN context, it will require all measures to remove discrimination against ASEAN suppliers of goods, services and factors. ASEAN still has indeed a long way to go to achieve a single market. To do so will require a fundamental change in thinking by ASEAN economic policy-makers especially in the way they approach regional economic integration. The relatively successful AFTA implementation (trade-related liberalizations) more or less has left issues concerning factor mobility at the top of the AEC implementation programs.

1 These 12 priority sectors are: electronics, information and communications technology (ICT), healthcare, wood-based products, automotives, rubber-based products, textiles and apparels, agro-based products, fisheries, air travel, tourism and logistics. 
This paper tries to shed some lights regarding what will happen after fully free factor mobility are achieved following the establishment of AEC in 2015 and as a way to strengthen analytical tools to anticipate ASEAN Economic Community 2015. Such objectives were clearly stated by Governor of Bank Indonesia at the Annual Bankers' Dinner January 18, 2008. In this annual strategy presentation, the Governor noted as follows (see Abdullah, 2008, page 154):

"The third initiative in the monetary sector is strengthening policy analysis related to AEC 2015. The ASEAN Charter in Singapore on $20^{\text {th }}$ November 2007 witnessed the introduction of the ASEAN economic integration program that is no longer up for negotiation. The AEC 2015 intra ASEAN free-trade agenda is nearly complete and will usher in a significant change in the movement of the production factor. The effect of free movement in the production factor is the establishment of a new configuration of intra ASEAN economic production distribution. It is therefore imperative for a central bank to understand the determinants of this new configuration. We need to project new characteristics and determinants of economic production distribution. As we are discussing something that will take place in the future, we do not have any data that can be interpreted through empirical study. Therefore, Bank Indonesia will initiate several theoretical and analytical research programs."

Fundamentally, a surge of regional integration agreements over the past two decades, including the formation of the ASEAN Economic Community, have sought to reduce barriers to the exchange of goods, services and, in the extreme, factors of production among subsets of countries. $^{2}$ Other examples include the NAFTA (United States, Canada and Mexico), the European Union's "Europe 1992" internal market program, the recent accession of additional countries into the European Union (EU), and ongoing efforts to initiate or renew agreements among a variety of nations (e.g., the Free Trade for the Americas and MERCOSUR). The literature dealing with the economic implications of regional integration has mostly dealt with the effects of reducing barriers to the movement of goods. Less attention has been given to the implications of also allowing greater mobility of productive factors within an integrated economy. This omission from the literature is important not only because cross-border factor flows are becoming increasingly important, ${ }^{3}$ but also the international trade literature has long recognized that goods trade and cross-border factor flows can evidence a substitute or complement relationship. Hence, reducing barriers to the movement of productive factors within an integrated area would be expected to affect the final distribution of production across members of an integrated economy.

2 Sachs and Warner (1995) chronicle these liberalization efforts.

3 The importance of factor mobility in many parts of the world is evidenced by the growing importance in many nations' balance of payments of remittances from abroad (e.g., International Monetary Fund, 2004). Capital flows in the form of foreign direct investment continue to be important among industrialized countries and they are increasingly also being directed toward developing countries. 
In this paper we take a general form (not an ASEAN specific) to investigate the implications of allowing factor mobility within an integrated economy for the distribution of production across members. Employing factor price equalization as a driving force, we show that factor mobility among members of an integrated economy (IE) implies that each member's share of total IE output will equal its shares of the total IE stock of each productive factor (i.e., its shares of total physical and human capital). We term this theoretical prediction the "equal-share" relationship.

\section{THEORY}

\section{II.1. The Model}

We consider an economy (or economic unit) that produces a single good by means of a constant return to scale production function: ${ }^{4}$

$$
Y_{t}=F\left(K_{t}, H_{t}\right) \text {. }
$$

where $Y_{t}$ is the level of output, $K_{t}$ is the level of physical capital stock and $H_{t}$ is the level of human capital stock, all at time $t$. To facilitate interpretation we assume the production function takes the Constant Elasticity of Substitution (CES) form:

$$
Y_{t}=\left\{K_{t}^{-}+(1-) H_{t}^{-}\right\}^{-1 /}
$$

where $\gamma$ is an efficiency parameter, $\delta$ the degree of physical capital usage, and $\rho$ is a substitution parameter such that the elasticity of substitution between the two inputs is $\alpha=1$ $/(1+\rho)$. Given (II.2), the marginal product of physical capital is:

$\left(F_{K}\right)_{t}=\gamma \delta\left\{\delta+(1-\delta)\left(\frac{K_{t}}{H_{t}}\right)^{\rho}\right\}^{-(1+\rho) / \rho}$

Combining (II.2) and (II.3) one can write:

$$
\left(F_{K}\right)_{t}=\gamma^{-\rho} \delta\left(\frac{Y_{t}}{K_{t}}\right)^{1+\rho}
$$

Similarly, the expression for the marginal product of effective labor (human capital) is:

4 For a complete discussion see Bowen, Munandar and Viaene (2005). 
$\left(F_{H}\right)_{t}=\gamma(1-\delta)\left\{(1-\delta)+\delta\left(\frac{K_{t}}{H_{t}}\right)^{\rho}\right\}^{-(1+\rho) / \rho}$

or

$$
\left(F_{H}\right)_{t}=\gamma^{-\rho}(1-\delta)\left(\frac{Y_{t}}{H_{t}}\right)^{1+\rho}
$$

We now introduce a second economy and consider the implications of allowing factor mobility between the two economies. If physical capital and human capital are perfectly mobile between the two economies then we would expect each factor to flow from the low to high rate of return country until each factor's rate of return (marginal product) is equalized between the two economies. However, if there are barriers to factor mobility then rates of return will only be partially equalized. ${ }^{5}$ For simplicity, we can represent such barriers by a time-varying proportional wedge in rates of return to physical capital $\left(\lambda_{t}(\mathrm{k})>0\right)$ and rates of return to human capital $\left(\lambda_{t}(h)>0\right)$. Given this, the relation between the rates of return between the two economies can be written:

$$
\begin{aligned}
& \gamma^{-\rho} \delta\left(\frac{Y_{t}}{K_{t}}\right)^{1+\rho}=\lambda_{t}(k)\left(\gamma^{*}\right)^{-\rho^{*}} \delta *\left(\frac{Y_{t}^{*}}{K_{t}^{*}}\right)^{1+\rho^{*}} \\
& \gamma^{-\rho}(1-\delta)\left(\frac{Y_{t}}{H_{t}}\right)^{1+\rho}=\lambda_{t}(h)\left(\gamma^{*}\right)^{-\rho^{*}}(1-\delta *)\left(\frac{Y_{t}^{*}}{H_{t}^{*}}\right)^{1+\rho^{*}}
\end{aligned}
$$

where ${ }^{* \prime}$ indicates second economy variables. The ratio of (II.7) to (II.8) gives the ratio of human to physical capital:

$$
\frac{H_{t}}{K_{t}}=\eta\left(\lambda_{t}\right)^{1 /(1+\rho)}\left(\frac{H_{t} *}{K_{t} *}\right)^{\theta}
$$

5 Barriers to capital mobility can include sovereign and political risk, capital controls, and tax differences that can hinder cross-border investments. Barriers to human capital mobility include government regulations on immigration and work permits, differences in pension systems and languages between countries. 
where :

$\eta=[\delta *(1-\delta) /(1-\delta *) \delta]^{1 /(1+\rho)}$, implying $\eta=1$ when $\delta=\delta^{*} ;$

$\theta=(1+\rho *), /(1+\rho)$, implying $\theta=1$ when $\rho=\rho *$;

$\lambda_{t}=\lambda_{t}(k) / \lambda_{t}(h)$, implying $\lambda_{t}=1$ when $\lambda_{t}(k) / \lambda_{t}(h)$.

Using these definitions we can write (7) as:

$$
\frac{Y_{t}}{K_{t}}=v \omega\left(\lambda_{t}(k)\right)^{1 /(1+\rho)}\left(\frac{Y_{t} *}{K_{t} *}\right)^{\theta}
$$

where:

$$
\begin{aligned}
& v=(\delta * / \delta)^{1 /(1+\rho)} \\
& \omega=\left[\left(\gamma^{*}\right)^{-\rho^{*}} \gamma^{\rho}\right]^{1 /(1+\rho)}
\end{aligned}
$$

We are now fully equipped to illustrate the implications of the model for the distribution of output and factors between the two economies. To show the role of human capital, rewrite (II.8) as:

$$
\frac{Y_{t}}{H_{t}}=\frac{\omega \eta}{\mathrm{v}}\left(\lambda_{t}(h)\right)^{1 /(1+\rho)}\left(\frac{Y_{t}^{*}}{H_{t}^{*}}\right)^{\theta}
$$

Traditionally, (II.11) serves as a basis for productivity calculations and comparisons across countries. However, unlike the existing literature (e.g., Hall and Jones, 1999) where productivity is measured by output per worker, equation (II.11) expresses (like the endogenous growth literature) productivity in terms of output per effective unit of labor. For the sake of comparison, consider Hall and Jones' (1999) example of the United States and Niger. In 2000, US output per worker was 38 times higher than output per worker in Niger. Using as a measure of human capital the number of persons with at least a secondary education, output per unit of human capital in Niger is instead measured to be 1.3 times higher than in the United States for the same period. This indicates the sensitivity of productivity comparisons to the measurement of human capital.

To obtain a first expression of the equal-share relationship, note that (9) and (10) can be written as follows:

$$
\frac{H_{t}}{K_{t}}=\eta\left(\lambda_{t}\right)^{1 /(1+\rho)}\left(\frac{H_{t}^{*}}{K_{t}^{*}}\right)^{\theta}=\frac{H_{t}+\left(H_{t}^{*}\right)^{\theta} \eta\left(\lambda_{t}\right)^{1 /(1+\rho)}}{K_{t}+\left(K_{t} *\right)^{\theta}}
$$




$$
\frac{Y_{t}}{K_{t}}=v \omega\left(\lambda_{t}(k)\right)^{1 /(1+\rho)}\left(\frac{Y_{t}^{*}}{K_{t}^{*}}\right)^{\theta}=\frac{Y_{t}+\left(Y_{t}^{*}\right)^{\theta} v \omega\left(\lambda_{t}(k)\right)^{1 /(1+\rho)}}{K_{t}+\left(K_{t}^{*}\right)^{\theta}}
$$

Combining these two expressions gives:

$$
\frac{H_{t}}{H_{t}+\left(H_{t}^{*}\right)^{\theta} \eta \lambda_{t}^{1 /(1+\rho)}}=\frac{Y_{t}}{Y_{t}+\left(Y_{t}^{*}\right)^{\theta} v \omega \lambda_{t}(k)^{1 /(1+\rho)}}=\frac{K_{t}}{K_{t}+\left(K_{t}^{*}\right)^{\theta}}
$$

Equation (II.12) establishes a link between the first economy's shares of the total output, physical capital, and human capital across the two economies. Differences in technology between the two economies imply only a rescaling of the original variables. A difference between $\gamma *$ and $\gamma$ indicates a neutral difference in technologies that has no effect on the optimal selection of physical capital and human capital, but it does have an effect on the distribution of output through in $\omega$ (II.12). A difference between the substitution elasticities introduces the power $\theta$ whereas differences between the other parameters lead to a multiple rescaling of variables.

Equation (II. 12) nests several share relationships that relate to different assumptions about technology and factor mobility. If technology is identical between the two economies then (II.12) simplifies to:

$$
\frac{H_{t}}{H_{t}+H_{t} * \lambda_{t}^{1 /(1+\rho)}}=\frac{Y_{t}}{Y_{t}+Y_{t} * \lambda_{t}(k)^{1 /(1+\rho)}}=\frac{K_{t}}{K_{t}+K_{t}^{*}}
$$

In this new form of the equal-share relationship, some variables for the second economy are rescaled by the proportional differences in rates of return. For example, from (II.13), an absence of barriers to physical capital mobility $\left(\lambda_{t}(k)=1\right.$ implies equal output and physical capital shares that, however, differ from the human capital share. If we assume that both $\left(\lambda_{t}(k)\right.$ $=1$ and $\left(\lambda_{t}(h)=1\right.$ then the equal-share relationship takes the simple form:

$$
\frac{H_{t}}{H_{t}+H_{t}^{*}}=\frac{Y_{t}}{Y_{t}+Y_{t}^{*}}=\frac{K_{t}}{K_{t}+K_{t}^{*}}
$$

This states that when there are no barriers to factor mobility and technologies are identical, each economy's shares of total output, total physical capital and total human capital will be identical. 
The equal-share relationship (II.14) has three main implications. First, a reallocation of physical capital between IE economies, that is, $d K_{t}=-d K_{t^{\prime}}$ must be accompanied by an increase in output and either an inflow of foreign human capital or an accumulation of domestic human capital to rebalance the equality of world shares. Similarly, a policy that increases a country's share of total IE human capital will raise both the country's share of total IE output and its share of total IE physical capital (via either an inflow of foreign physical capital or accumulation of domestic capital).

Second, our framework can be related to the broad topic of output convergence by noting that if (II.14) holds then the following two equalities will also hold:

$$
\begin{aligned}
& \frac{Y_{t}}{H_{t}}=\frac{Y_{t}+Y_{t}^{*}}{H_{t}+H_{t}^{*}} \\
& \frac{Y_{t}}{H_{t}}=\frac{Y_{t}^{*}}{H_{t}^{*}}
\end{aligned}
$$

From (II.16) it is clear that, if the equal-share relationship holds, the two economies will have the same output per efficiency unit of labor. This implication is the essence of the productivity convergence hypothesis (Baumol, 1986), here interpreted in terms of efficiency units of labor and not per capita.

Third, the equal-share relationship (II.14) can be extended to the case of an integrated economy that comprises $j=1, \ldots, N$ members. If all members have the same technology, and there is perfect mobility of either physical or human capital among members, then the equalization of factor rates of return implies:

$$
\frac{H_{i t}}{\sum_{j=1}^{N} H_{j t}}=\frac{Y_{i t}}{\sum_{j=1}^{N} Y_{j t}}=\frac{K_{i t}}{\sum_{j=1}^{N} K_{i t}} \text { for } i=1, \ldots, N
$$

This set of equalities express the distribution of output and factors among $\mathrm{N}$ members of a fully integrated economy. Like (II.12), expression (II.17) can be extended to allow for differences in technology and factor market imperfections among members.

In the context of the ASEAN Economic Community (AEC), the equal share relationship can predict the limiting distribution of production among ASEAN members after 2015. Countries with more human capital and therefore have high proportions of total human capital will have larger proportions of physical capital and bigger shares in the pie of regional economic output. 
This makes sense since superior quality human resources become a magnet for and complement advanced technology-intensive physical capital, while technology has the capability of delivering improvement in economic productivity exponentially.

In addition, ASEAN countries able to offer the most conducive atmosphere (read: policies) for foreign investment have the greatest opportunities for acquiring the largest share of physical capital in relation to other ASEAN countries. Besides this, a more advanced economy will support a higher rate of domestic investment by the public, which will also expand the proportion of physical capital in that country. A nation with substantial physical capital (financial and nonfinancial) will be able to employ highly skilled domestic and foreign labours that represent a powerful source of energy for high quality and sustainable economic growth.

Each ASEAN member will occupy a certain ranking among the AEC participating countries in terms of economic output, human capital and physical capital, commensurate to that country's resources and the economic policies that it chooses to adopt. Needless to say, there will be great interest in answering this question: Where will Indonesia stand?

\subsection{Equal Share Relationship, Investment and Monetary Policy}

From (II.17) it is observed that in an integrated economy where barriers to factor mobility no longer exist and the production technology is increasingly uniform, the share of total output, total physical capital and total human capital of a nation is becoming more identical. Nations with a small share of output will have a comparably small proportion of capital stock (physical and human).

The implication of this relationship is that reallocation of physical capital (investment) to a country will result in an increase in that country's output accompanied by inflows of foreign human capital or accumulation of domestic human capital. As a result, policies to create a conducive investment climate and improvement of human capital are vital not only for a country to become competitive, but also for national survival. A reduced share of human capital will also lead to a deterioration in economic output and in turn a decline in the living standards of the people of that economy.

Considered further, a strategy to build human capital requires implementation of longterm policies involving commitment, major budget expenditures and untiring hard work, particularly in the world of education, and hence the role of central bank in this area is very limited. On the other hand, however, the central bank could do something in relation to the strategy to accumulate physical capital. A significant increase in physical capital requires high investment from domestic sources (accumulation of private savings) and foreign sources (FDI inflows). 
Some studies have attempted to investigate the possibility of a linkage between monetary policy performance (the central bank domain) and investment levels. At the theoretical level, Barro (1996) made the conceptual discovery that the effect of inflation on growth and investment is negative, while Agenor (2004) claims that improved macroeconomic stability in response to appropriate policies leads to increased savings and investment. In this regard, it is important and interesting to examine whether empirical evidence can be found in the case of Indonesia. The search for this evidence becomes highly important when linked to the imminent formation of the ASEAN Economic Community in 2015. It is therefore crucial to study whether a significant relationship exists between monetary policy performance (most importantly inflation) and investment performance in the ASEAN countries (mainly FDI inflows). If this relationship is discovered, the monetary authority can play a role in building a nation's physical capital, which will lead to expansion in that nation's share of economic output (read: prosperity). In other words, the monetary authority may have a positive role in the period leading up to the establishment of the ASEAN Economic Community (AEC).

\section{METHODOLOGY}

To validate the possible existence of the above linkages, an empirical study is conducted using macroeconomic data from the ASEAN-7 countries (Philippines, Indonesia, Cambodia, Malaysia, Singapore, Thailand and Vietnam) for the 1991-2006 period. The first phase of this study involved a short-term analysis using data on investment, inflation and real annual GDP for each country obtained from the International Monetary Fund (IMF) and Asian Development Bank (ADB). ${ }^{6}$ In the short-term, the model specifications used are as follows:

Model 1: $y_{t}=a_{1}+b_{1} x_{1}, t-\varepsilon_{1}$,

Model 2: $y_{t}=a_{2}+b_{2} x_{2}, t-1+\varepsilon_{2}$,

in which $y_{t}$ is investment growth in year $\mathrm{t}, \mathrm{x}_{1, \mathrm{t}-\mathrm{s}}$ is inflation in the preceding year and $\mathrm{x}_{2, \mathrm{t}-1}$ is real GDP growth in the preceding year. $\varepsilon_{1, t}$ is assumed to have the IID property. The above specifications attempt to capture the nature of the relationship between inflation and economic growth in one period and investment growth in a subsequent period. A significant $b 1$ or $b 2$ coefficient values will confirm the existence of this relationship. Theoretically, the b1 value is negative (high inflation reduces investment) and the b2 value is positive (economic growth will promote investment growth).

6 The IMF data is the International Financial Statistics (IFS) covering a number of years. 
The long run analysis uses cross-section data for inward FDI in 2006 and cross-section data for average inward FDI in the 2002-2006 period for the above seven ASEAN countries. The use of these averages is aimed at minimising volatility in the FDI data. As can be seen, 2006 is used as the reference year. Long-term inflation is calculated for each cross-section data using average annual CPI inflation for the 1991-2005 period, while macroeconomic instability is proxied by a standard deviation of nominal GDP growth, also for the 1991-2005 period. Data on FDI inflows from the International Monetary Fund is used for investment levels in the long run analysis. The long run regression model is prepared as follows:

Model 4: $y_{i}=c_{1}+d_{1} x_{1, i}+\varepsilon_{3}$,

Model 5: $y_{i}=c_{2}+d_{2} x_{2, i}+\varepsilon_{4}$,

where $y_{i}$ is FDI inflows to country $i, x_{1, i}$ is long-term inflation in country $i$ and $x_{2, i}$ is the level of macroeconomic instability in country i. $\varepsilon_{3}$ and $\varepsilon_{4}$ are assumed to have IID properties. The above specifications attempt to capture the nature of the relationship between long-term inflation in combination with macroeconomic stability on FDI inflows in ASEAN countries. A significant $d_{1}$ or $d_{2}$ coefficient value will confirm this relationship. Theoretically, low long-term inflation will promote FDI inflows while high levels of macroeconomic instability will deter inward FDI.

\section{RESULT AND ANALYSIS}

\section{IV.1. Short-Run Analysis}

The results of the short run (annual) regression analysis are presented in Tables II.1 to II.7. In some countries (including Indonesia and Thailand), low annual inflation and real GDP growth are associated with investment growth. However, this linkage is less convincing in the case of other ASEAN countries in the study (Cambodia, Malaysia, the Philippines, Singapore and Vietnam), and results are therefore inconclusive.

\begin{tabular}{|c|c|c|c|c|}
\hline \multirow{2}{*}{\multicolumn{5}{|c|}{$\begin{array}{l}\text { Table II.1 } \\
\text { Investment Growth and Macroeconomic Performan } \\
\text { THAILAND }\end{array}$}} \\
\hline & & & & \\
\hline & \multicolumn{2}{|c|}{ Sample : 2002-2006 } & \multicolumn{2}{|c|}{ Sample : 1992-2006 } \\
\hline & Model 1 & Model 2 & Model 1 & Model 2 \\
\hline $\begin{array}{l}\text { Annual Inflation (-1) } \\
\text { Real GDP Growth (-1) }\end{array}$ & $\begin{array}{c}-0.006 \\
(0.8086)\end{array}$ & $\begin{array}{c}0.030 \\
(0.0319)\end{array}$ & $\begin{array}{c}-0.035 \\
(0.0696)\end{array}$ & $\begin{array}{c}0.018 \\
(0.0354)\end{array}$ \\
\hline
\end{tabular}




\begin{tabular}{|c|c|c|c|c|}
\hline \multicolumn{5}{|c|}{$\begin{array}{l}\text { Table II. } 2 \\
\text { croeconomic Performance in Indonesia }\end{array}$} \\
\hline & \multicolumn{4}{|c|}{ INDONESIA } \\
\hline & \multicolumn{2}{|c|}{ Sample : 2002-2006 } & \multicolumn{2}{|c|}{ Sample : 1992-2006 } \\
\hline & Model 1 & Model 2 & Model 1 & Model 2 \\
\hline $\begin{array}{l}\text { Annual Inflation (-1) } \\
\text { Real GDP Growth (-1) }\end{array}$ & $\begin{array}{c}-0.028 \\
(0.0250)\end{array}$ & $\begin{array}{c}0.070 \\
(0.2783)\end{array}$ & $\begin{array}{l}-0.005 \\
(0.0023)\end{array}$ & $\begin{array}{c}0.012 \\
(0.0124)\end{array}$ \\
\hline
\end{tabular}

\begin{tabular}{|c|c|c|c|c|}
\hline \multirow{2}{*}{\multicolumn{5}{|c|}{$\begin{array}{l}\text { Table II.3 } \\
\text { croeconomic Performan } \\
\text { KAMBOJA }\end{array}$}} \\
\hline & & & & \\
\hline & \multicolumn{2}{|c|}{ Sample : 2002-2006 } & \multicolumn{2}{|c|}{ Sample : 1992-2006 } \\
\hline & Model 1 & Model 2 & Model 1 & Model 2 \\
\hline $\begin{array}{l}\text { Annual Inflation (-1) } \\
\text { Real GDP Growth (-1) }\end{array}$ & $\begin{array}{c}-0.009 \\
(0.6111)\end{array}$ & $\begin{array}{c}0.006 \\
(0.7109)\end{array}$ & $\begin{array}{c}0.002 \\
(0.2095)\end{array}$ & $\begin{array}{c}-0.001 \\
(0.9830)\end{array}$ \\
\hline
\end{tabular}

\begin{tabular}{|c|c|c|c|c|}
\hline \multicolumn{5}{|c|}{$\begin{array}{c}\text { Table II.4 } \\
\text { Investment Growth and Macroeconomic }\end{array}$} \\
\hline & \multicolumn{4}{|c|}{ SINGAPURA } \\
\hline & \multicolumn{2}{|c|}{ Sample : 2002-2006 } & \multicolumn{2}{|c|}{ Sample : 1992-2006 } \\
\hline & Model 1 & Model 2 & Model 1 & Model 2 \\
\hline $\begin{array}{l}\text { Annual Inflation (-1) } \\
\text { Real GDP Growth (-1) }\end{array}$ & $\begin{array}{c}-0.017 \\
(0.8380)\end{array}$ & $\begin{array}{c}0.014 \\
(0.2882)\end{array}$ & $\begin{array}{c}0.038 \\
(0.1042)\end{array}$ & $\begin{array}{c}0.012 \\
(0.0638)\end{array}$ \\
\hline
\end{tabular}

\begin{tabular}{|c|c|c|c|c|}
\hline Investme & vth and & onomic P & nce in $M t$ & \\
\hline & \multicolumn{2}{|c|}{ Sample : 2002-2006 } & \multicolumn{2}{|c|}{ Sample : 1992-2006 } \\
\hline & Model 1 & Model 2 & Model 1 & Model 2 \\
\hline $\begin{array}{l}\text { Annual Inflation (-1) } \\
\text { Real GDP Growth (-1) }\end{array}$ & $\begin{array}{c}0.036 \\
(0.2049)\end{array}$ & $\begin{array}{c}0.011 \\
(0.1636)\end{array}$ & $\begin{array}{c}0.019 \\
(0.6281)\end{array}$ & $\begin{array}{c}0.013 \\
(0.2173)\end{array}$ \\
\hline
\end{tabular}


Table II.6

Investment Growth and Macroeconomic Performance in the Philippines

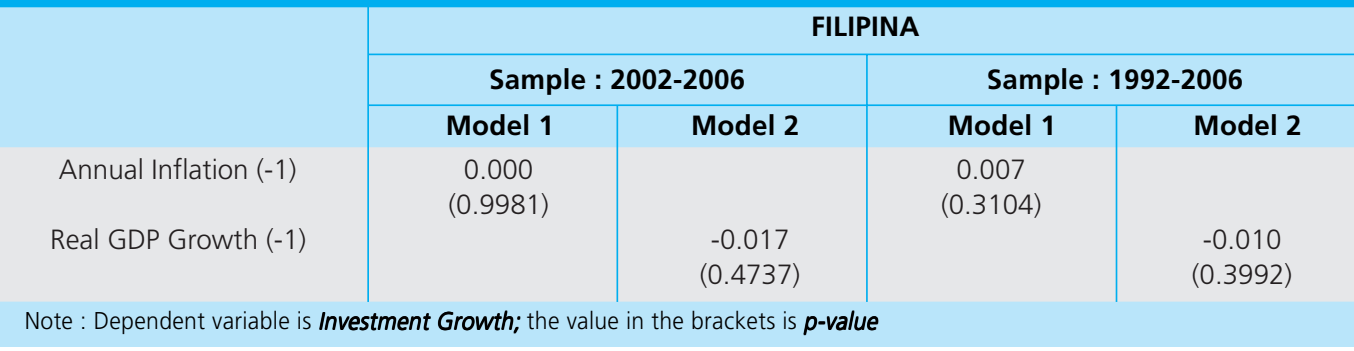

Table II.7

Investment Growth and Macroeconomic Performance in Vietnam

\begin{tabular}{|c|c|c|c|c|}
\hline & \multicolumn{4}{|c|}{ VIETNAM } \\
\hline & \multicolumn{2}{|c|}{ Sample : 2002-2006 } & \multicolumn{2}{|c|}{ Sample : 1992-2006 } \\
\hline & Model 1 & Model 2 & Model 1 & Model 2 \\
\hline $\begin{array}{l}\text { Annual Inflation (-1) } \\
\text { Real GDP Growth (-1) }\end{array}$ & $\begin{array}{c}-0.003 \\
(0.4570)\end{array}$ & $\begin{array}{c}-0.024 \\
(0.2468)\end{array}$ & $\begin{array}{c}0.007 \\
(0.0000)\end{array}$ & $\begin{array}{c}0.007 \\
(0.8188)\end{array}$ \\
\hline
\end{tabular}

The findings of the short run analysis must be treated with caution. On one hand, the results obtained are dependent on the business cycle in individual countries, and therefore it is difficult to identify a uniform pattern within ASEAN. On the other hand, an interesting aspect of economic integration concerns its effect in the long run, not short run. In addition, country investment policies are generally focused on foreign capital inflows, given that domestic investment tends to be stable. FDI is the most desired of all types of foreign investment because of the more direct implication it has on the real sector (compared to the effect of portfolio investment which tends to be confined to the financial sector). Therefore, attracting the maximum possible FDI is the goal of many developing nations, including those in ASEAN. The long run analysis in the following section attempts to explain these issues.

\section{IV.2. Long-Run Analysis}

The results of a long run analysis appear in Table II.8 and II.9. Both tables indicate to a strong correlation between low inflation and high rates of inward FDI. Countries that succeed in achieving a consistent level of low inflation will benefit from high inflows of FDI. 


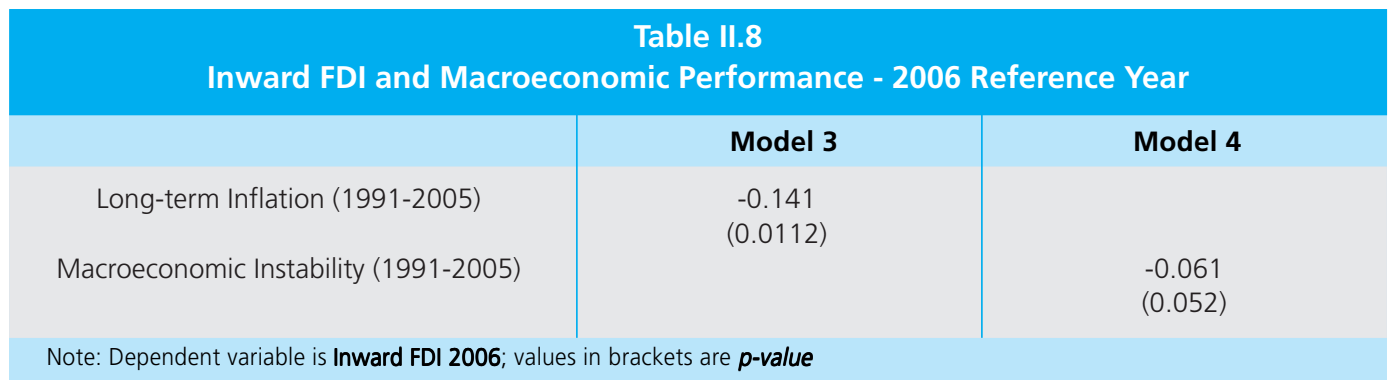

\begin{tabular}{|c|c|c|}
\hline \multicolumn{3}{|c|}{ Table II.9 } \\
\hline & Model 3 & Model 4 \\
\hline $\begin{array}{l}\text { Long-term Inflation (1991-2005) } \\
\text { Macroeconomic Instability (1991-2005) }\end{array}$ & $\begin{array}{c}-0.148 \\
(0.0031)\end{array}$ & $\begin{array}{c}-0.064 \\
(0.0325)\end{array}$ \\
\hline
\end{tabular}

The results also demonstrate a strong correlation between macroeconomic stability and FDI inflows. Countries with stable macroeconomic conditions enjoy high rates of FDI, and the converse also applies. Both results are valid for all ASEAN countries under study. The conclusion from this analysis seems to be that central bank policy aimed at achieving and maintaining low inflation and stable macroeconomic conditions is a pro-investment monetary policy.

\section{v . CONCLUSION}

Regional economic integration will result in an economic distribution that depends on distribution of each country's production factors, comprising both physical capital and human capital. Investment will play an increasingly central role, directly determining a country's level of prosperity in relation to its peers in the region. Central banks are able to influence investment performance through their monetary policies: low inflation and stable macroeconomic conditions contribute significantly to increased investment. In other words, monetary policy targeting low inflation and macroeconomic stability is a pro-investment monetary policy. With regional economic integration, central banks will play an increasingly essential role in promoting investment. 


\section{References}

Abdullah, B., 2008, "Opening the Path to Stability, Safeguarding the Nation's Economic Development," Address by Governor of Bank Indonesia at the Annual Bankers' Dinner.

Agenor, P. R., 2004, Macroeconomic Adjustment and the Poor: Analytical Issues and CrossCountry Evidence, Journal of Economic Surveys, 18(3), 351-408.

Barro, R. J., 1996, Inflation and Growth, Federal Reserve Bank of St. Louis Review, 78, May/ June, 153-169.

Baumol, W. J., 1986, Productivity Growth, Convergence, and Welfare: What the Long-Run Data Show, American Economic Review 76, 1072-1085.

Bowen, H.P., H. Munandar and J.-M. Viaene (2005), The Limiting Distribution of Production in Integrated Economies: Evidence from U.S. States and E.U. Countries, Tinbergen Institute Discussion Paper 05-045/2.

Hall, R.E. and C.I. Jones, 1999, Why Do Some Countries Produce So Much More Output Per Worker Than Others?

International Monetary Fund, 2004, International Financial Statistics, Washington DC: International Fund.

Sachs, J.D. and A. Warner, 1995, Economic Reform and the Process of Global Integration, Brookings Papers on Economic Activity, 1-95. 
halaman ini sengaja dikosongkan 